\title{
THE EFFECTIVENESS OF MICRO-LEARNING IN RETAIL BANKING
}

\section{Madden}

Masters graduate at Da Vinci Institute for Technology Management

Johannesburg, South Africa

e-mail: meryl.madden@fnb.co.za / http://orcid.org/0000-0002-9164-0948

\section{K. K. Govender}

School of Management, IT and Governance

University of KwaZulu-Natal

Durban, South Africa

e-mail: govenderkrishna@gmail.com / http://orcid.org/0000-0002-3079-5989

\section{ABSTRACT}

In order to remain competitive in a global technological revolution, the learning and development departments of businesses are focusing on the emerging concept of micro-learning, to support the fast-paced, multitask orientated and digitally savvy learners. A survey was conducted among 7673 employees of one of the major retail banks in South Africa, to determine the effectiveness of micro-learning and establish whether micro-learning is effective, as well as identify gaps and recommend strategies to close them. Through inferential statistical analysis of the data, it was concluded that learners reacted positively to micro-learning, the acquired relevant knowledge using micro-learning which improved work performance and business metrics. Although the microlearning programme was deemed effective for the vast majority ( $80 \%)$ of the participants, two gaps were identified, namely, micro-learning did not fully embrace the social tenet of learning, and it is also not exempt from the distractions that learners experience. It is recommended that any organisation pursuing a micro-learning programme should incorporate a social knowledge-sharing element into the programme and provide users with tools to develop self-control and selfregulation habits needed to conquer constant distractions.

Keywords: learning, knowledge, micro-learning, bank

\section{INTRODUCTION}

The Fourth Industrial Revolution (4IR) is characterised by the "digital enhancement and mutual connections of any components under the control or influence of modern day intelligent systems" (Saniee et al. 2017), this includes advances made in artificial intelligence, automation, engineering, technology, and robotics, (Younus 2017), as well as developments in data analytics, data storage, social networks, and mobile platforms, (Bloem et al. 2014). The 4IR has transformed the way society, the economy and business models, operate at a fundamental level, and this requires a rewriting of the rules for every organisational "people practice", including 
learning and development (L\&D) (Deloitte 2017). As social and other media platforms change, so does learning itself(Hug 2007), and it is in this context that the "modern adult learner" needs to be understood.

Since the concept of the adult learner was first introduced by Knowles in the 1970s (Knowles, Holton and Swanson 2012), learning and development in organisations have undergone notable transformation. The traditional learning environment no longer serves the needs of the overwhelmed and distracted adult learner who can only devote about one percent of their time per work week on work-related learning and professional development (Deloitte 2014). In the current work environment, employess are constantly required to learn, adapt to new situations and meet new and changing demands and challenges; thus new information needs to be continuously acquired and applied (Bruck 2006). Outdated models of instruction built for a different era are thus not adequate for ongoing development of the modern learner, as they contain learners to restrictive systems where there is no interaction with the external performing environment (Buchem and Hamelmann 2010). Moreover, in the current media environment, where digital media has become ubiquitous, there is no way back and people must learn using digital media (Neuhold and Lindner 2007).

Over the last 20 years, corporate training has already been through four evolutions, each driven by technological and economic change, with the current changes triggering the need for new ideas and approaches to support lifelong learning in the digital era (Bersin 2018). Microlearning seems to provide a possible solution to the fast-paced, always-on and multitaskorientated patterns of the modern learning and working today (Buchem and Hamelmann 2010). The business rationale supporting the move to micro-learning is supported by research which indicates that most learners are interested in learning via electronic devices (Jomah et al. 2014), and the vast majority of learners will welcome a modern version of micro-learning software.. Learners are looking to a simple and smart learning system that can deliver micro-content to transform knowledge (Jomah et al. 2014) and allow them to capitalise on the limited time they have available to develop work related skills and professional growth. Given that learning and development enhances individual's capabilities, it is thus an important lever that business can use to improve their competitive advantage in the 4IR era (Bell et al. 2017), these transformational changes create new challenges.

Microlearning as a term reflects, is the emerging reality of the ever-increasing fragmentation of both information source and information units used for learning, especially in fast-moving areas, which see rapid development and constantly high degree of change. It is clear that workplace training has undergone a transformation, and technological advances now allow learning to occur on demand and virtually anywhere and at any time. Given that the role 
of learning and development does not only serve as a function to enhance individual capabilities, but is also a valuable lever for business to gain a competitive advantage in the 4IR era (Bell et al. 2017), these transformational changes create new challenges.

Microlearning, as a concept defined by the ability to access small units of narrow topics that form part of an inter-connected curriculum, via an "anytime and anywhere"-enabled technology platform, in under 15 minutes, has the benefit of allowing the adult learner to take their learning beyond the boundaries of a bricks-and-mortar learning environment, and enables them to integrate their learning into their daily lives by reducing the overflow and complexity of information.

Despite the inconclusive and polyvocal nature of micro-learning, researchers argue that the discourse is good and should be cultivated to encourage the micro-learning agenda in the present age, especially as organisations aspire towards certainty; whether in the creation of shareholder value, or new models of education (Siemens 2007). This need for certainty is further intensified with micro-learning creating loopholes in the learning process, as the assimiliation of knowledge can occur without pre-established objectives, and without external control and evaluation (Hierdeis 2007) and where the didactic approach of deliberative learning is taken and prepared content is pushed in micro-learning, it is based on incommensurable ideas (Schmidt 2007).

In light of the above, a survey was conducted among a population 7673 retail bank employees of one of the largest retail banks in South Africa, to determine the effectiveness of micro-learning and establish whether micro-learning is effective, identify any gaps that exist and make recommendations to close those gaps.

\section{RESEARCH CONTEXT}

In the global banking industry, changes in what customers expect, advances in technological capabilities, new regulatory requirements, and shifts in demographics and economics are creating an imperative to change (PWC 2014). Thus to maintain a competitive advantage, banks have had to develop solutions to meet the rapidly changing needs of customers (Camarate and Brinckmann 2017). South Africa has a well-regulated and mature banking system which compares favourably with those of industrialised countries. According to the World Economic Forum's Global Competiveness Survey, the South African Bankin Industry has been ranked 3rd out of 148 countries in the 2013/14 financial year. (The Banking Association of South Africa 2014). Of the 19 registered banks in South Africa (SARB 2017), the industry is dominated by the "four universal banks", more commonly referred to as "the big four" due to the substantial share of banking customers in South Africa serviced by these banks (Camarate 
and Brinckmann 2017).

This research takes place in the retail bank division of one of the "big four" banks which was voted the world's most innovative bank in 2012 (Brand South Africa 2012) and the most innovative bank in Africa in 2016 (Jugmohan 2016). It has a network of 775 branches across the country and 7000 branch delivery staff (Compare Banks 2014).

As with the global market, the domestic banking marketing landscape is changing and competition in the South African banking sector is growing (BusinessTech 2018). In response to the increasing competive threats in retail banking, models that incorporated digital solutions and other low-cost technologies have moved to the top of the business agenda (PWC 2015). The financial sector has been forced to become innovative and simplify products that have been previously been considered as complex and sophisticated (Nanziri and Leibbrandt 2018).

The changes in the global and domestic market have also meant a change in the role of learning and development (L\&D) departments becoming more strategic (FutureThink 2009). According to Eades (2015), in the current era, where it is becoming increasingly challenging to introduce new and improved products to the market, the thing that businesses cannot copy and paste, is its human capital. Thus, as people are a competitive edge, Learning and Development has become an strategic department in the business (Eades 2015).

The need for a low-cost learning solution that ensures timeous and improved product knowledge of 65 complex and sophisticated financial products among more than 7000 staff dispersed across 775 branches, was not just a project for the learning and development department, but a strategic imperative for the bank. The aforementioned task was further complicated since research (Deloitte 2014) argued that people have less than one percent of a typical work week to focus on learning and development. Thus, in July 2016, the research organization (major bank) invested in a three-year license for a micro-learning platform called Axonify, which allows for real-time and always-on learning.

Axonify is an employee knowledge platform that is available as an application on smartphones and was purpose-built, to provide the knowledge employees need to perform their jobs effectively (Axonify 2019). At the time the bank had invested in this technology, Axonify had been implemented in large corporations in the US, like Walmart and Toyota, since it promised to modernise learning and reduce execution risk in an increasingly complex environment (Axonify 2019). Since the Axonify license which was acquired by the bank in July 2016, was due to expire in June 2019, the executive requested that training be conducted to determine the value (if any) that accrued from using Axonify, so that a decision could be made on whether to renew the user licence. This prompted the primary researcher who is an employee in the bank, to conduct this study. 


\section{LITERATURE REVIEW}

\section{Workplace learning}

The demand on the workforce to be agile in their pursuit of of continuous learning, has given rise to a new standard of adult learning, with specific focus on learning in the workplace (Brooks 1990), and from the time the concept human capital has taken root, it has fuelled the need for workplace learning (Rainbird, Fuller and Munro 2004). Thus, learning has become important fixed item on many organisational agendas, and the training methods that have evolved from research in adult learning, has enabled workers to engage more efficiently in these constantly changing work environments (Le Clus 2011).

With the advent of the internet and subsequent rapid changes in technology, learning has changed in terms of how people learn, with whom they learn, and by what means they learn (Haythornthwaite and Andrews 2011). In the 21st century, knowledge has become the principal component of the modern economy, and the Knowledge Age has introduced a new mind set in society with profound implications for learning (Harasim 2012).

In the $21^{\text {st }}$ century, the purpose of learning has changed to enabling humans to solve complex problems in today's interconnected world (Isaias et al. 2015). This change has compelled thinking on learning to move beyond the traditional boundaries of bricks-and-mortar institutions towards new approaches of disseminating and integrating learning, and new learning paths by means of online or technology-supported learning, commonly known as elearning (Haythornthwaite and Andrews 2011). Whether known as online learning, e-learning, asynchronous learning, with a fundamentally different learning milieu of who learns from whom, where, and when, compared to traditional learning, online learning is viewed as critical to the mission of education (Haythornthwaite and Andrews 2011). The rapid adoption was further accelerated because of e-learning's capability to support self-directed learning, giving learners control over the contents and tools most appropriate to their interests, needs and level of skill (Kapur 2015). People can access the internet from any time and place via wireless communication infrastructure and mobile devices like smart phones as part of their daily lives (Haythornthwaite and Andrews 2011). This powerful combination of access to anytimeanywhere information, gives rise to new areas of learning such as mobile learning and ubiquitous learning (Haythornthwaite and Andrews 2011).

There were abour 2.32 billion smartphone users in the world, and 18.48 million smartphone users in South Africa by 2017 (Statista 2018). People are constantly connected. They can send and receive messages; access news, and live streams of information from any 
device in any location 24 hours a day; additionally, the average person spends about two hours per day on the most popular social platforms (Asano 2017). This information richness and abundance is a hallmark of the information society the modern learner finds themselves in (Bersin 2018). However, a consequence of this era of information overload is that some people feel that they have little, if any, time for formal training and development, just one percent of a typical week on average (Deloitte 2014), down from the five percent of time that knowledge workers had in 2008 to devote to thought and reflection during their day, which was already down from the twelve percent that was available in 2008 (Spira 2010).

It is the transition from information scarcity to information abundance, combined with the technological changes that make information available anywhere, any time and the reduced time available for formal training, that has triggered the shift to micro-learning. All forms of education, including adult learning in the work environment, needed transformation and required renewal in modern ways, relating appropriately to the way we live, work and learn today (Job and Ogalo 2012). Micro-learning is the response to two prominent learning frustrations: firstly there is the overflow and complexity of information, and the time and place to learn, with many in the learning community claiming that micro-learning can enable people to learn more effectively if information is broken down into smaller units (Abel, Moulin and Lenne 2006).

\section{Evaluating learning effectiveness}

With a focus on how workplace training impacts the fiscal bottom line, learning technology providers have had toshow monetary savings and other broader financial benefits (Strother 2002). While measuring cost savings in learning is one aspect, to further justify its relevance, Human Resource Development should also show that investing in the learning and development of an employee delivers business results (Spitzer 2005). Evaluation in terms of determining the effectives of a training programme has little meaning until it is determined what is being evaluated. Donald Kirkpatrick attempted a respond to this question in his $1954 \mathrm{PhD}$ dissertation entitled "Evaluating a Human Relations Training Program for Supervisors," and went on to write a four part series of articles for the American Society for Training and Development (ASTD): "Evaluating Reaction", "Evaluating Learning", "Evaluating Behaviour", and "Evaluating Results". More than 50 years after the Kirkpatrick four-level model was introduced, many new ideas about how to measure the effectiveness of learning have been developed, yet the four level Kirkpatrick model remains the dominant schema for evaluating the success of a learning intervention (Galloway 2005).

Despite its criticisms (Spitzer 2005), the simplicy of the Kirkpatrick Model is its main 
advantage as the four level framework provides a taxonomy that assists people to think about training evaluation criteria in an uncomplicated manner (Alliger and Janak 1989). The appeal of the Kirkpatrick Model for many learning practitioners lies in the model's propensity to simplify the complexity of training evaluation (Bates 2004), and the flexibility offered by its unsophisticated state (Abernathy 1992). Furthermore, it addresses the need to evaluate training systematicly, and it provides a straightforward approach when discussing training outcomes (Bates 2004).

In measuring the effectiveness of micro-learning, the question is whether the Kirkpatrick is model developed (more than 50 years ago) to evaluate classroom-orientated corporate training programmes, is still relevant? Current research concludes that existing training evaluation techniques and processes can address e-learning evaluation requirements (Strother 2002), and that in the age of computer technology, distance-delivery and online learning, Kirkpatrick's four level Model becomes more and not less relevant (Galloway 2005). Thus, the aforementioned model will be used to determine the effectiveness of the micro-learning programme (Axonify) in the retail bank.

\section{RESEARCH DESIGN AND METHODOLOGY}

Effectively evaluating learning is an imperative, since organisations are increasingly demanding data to demonstrate the impact of (investments) learning programmes (Deloitte 2017). Fortunately, more and more technology is being developed that enable Learning and Development teams to, evaluate and measure learning data (Downes 2019) and the challenge is no longer how to measure, but which established model of learning evaluation to use.

The researcher used Kirkpatrick's four-level training evaluation model (1959), which measures a learner's reaction to learning; their learning of new skills and knowledge; change in work-related behaviour; and a difference in business results. The researcher adopted a positivist research paradigm, since positivist thinkers apply scientific methods, systematically approach the knowledge generation process, and use quantification to enhance precision (Henning, Van Rensburg and Smit 2004). In line with the theoretical lens or research paradigm of this study, Downes (2019) confirms that Kirkpatrick's four level model is suited towards using quantitative research methods, and this also necessitated the use of a combination of two common quantitative methods, namely, survey research and correlational research (Creswell 2014)

\section{Research population and sample}

The population comprised all branch delivery staff employed during the period of October 2017 
to October 2018, which according to the banks Human Resources Headcount Tracker report (October 2018), was 7 673. Each of these staff members were identified by a unique employee number and they were given access to the micro learning platform. A convenient sampling approach was used since the micro-learning platform had also been used by other business units, but access to these users could not be obtained. For the level one evaluation on learner satisfaction and the level two evaluation of learning acquisition, the sample size was all 7673 branch delivery staff. For level three evaluation, two limitations were added which reduced the sample size to 1665 employees. The two filters were as follows: firstly, the employees had to have the same role title for all three performance review periods; October 2017, April 2018 and October 2018; secondly, they had to have a performance rating captured for each of those performance review periods. Effectively, if an employee's role title changed during the oneyear period, and/or they weren't rated for one of the periods, they would not be included in the sample for correlation testing at level 3, to establish if there is a link between the time spent on micro-learning and a change in performance.

For the level four evaluation, two limitations were added which reduced the sample size to 3445 employees. The two filters were as follows: firstly, the employees had to fulfil a sales role as part of their key performance indicators and secondly, they had to have sold products in 2017 and 2018. The difference between the two years' sales data is what was required for the correlation test at level 4 to establish if there is a link between the time spent on micro-learning and sales.

\section{Data collection}

Data was collected by means of three different research tools: a questionnaire, standardised test and a correlation test. The questionnaire formed the first data collection method, and its content was guided by the literature reviewed. The questionnaire (Table 1), whose purpose was to establish the levels of satisfaction with micro-learning one year since it had first been launched, comprised eight categories linked to the satisfaction of a learning programme: objectives; course materials; course relevance; facilitator; delivery; style; evaluation; and facility. Each of the categories indicated above consisted of sub-questions with a four-point Likert scale to determine the extent to which learners were satisfied.

The questionnaire was sent to all branch delivery staff across the country via the online micro-learning platform and a total of 5960 people responded to the questionnaire. 
Table 1: Questionnaire used to evaluate Satisfaction

\begin{tabular}{|c|c|c|c|c|c|}
\hline Category & Statement & 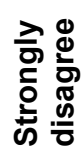 & 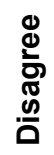 & ఖ & 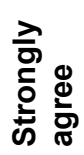 \\
\hline \multirow{3}{*}{$\begin{array}{l}\text { Programme } \\
\text { objectives }\end{array}$} & I understood the learning objectives. & & & & \\
\hline & I was able to relate to each of the learning objectives. & & & & \\
\hline & I was appropriately challenged by the material. & & & & \\
\hline \multirow{2}{*}{$\begin{array}{l}\text { Course } \\
\text { materials }\end{array}$} & The course material was easy to navigate. & & & & \\
\hline & I felt that the course material will be essential for my success. & & & & \\
\hline Relevance & The material was relevant to my needs. & & & & \\
\hline \multirow{3}{*}{ Facilitator } & $\begin{array}{l}\text { My learning could have been advanced if I had a facilitator } \\
\text { share their knowledge with me. }\end{array}$ & & & & \\
\hline & My learning was enhanced by the Discovery Zone. & & & & \\
\hline & $\begin{array}{l}\text { My learning could have been advanced if I had a facilitator } \\
\text { share their experiences with me. }\end{array}$ & & & & \\
\hline \multirow{4}{*}{ Delivery } & I was engaged during the course of the programme. & & & & \\
\hline & $\begin{array}{l}\text { I was able to get actively involved during the course of the } \\
\text { programme. }\end{array}$ & & & & \\
\hline & I was comfortable with the pace of the programme. & & & & \\
\hline & I was comfortable with the duration of the programme. & & & & \\
\hline \multirow{2}{*}{ Style } & $\begin{array}{l}\text { I was given ample opportunity to get answers to my } \\
\text { questions. }\end{array}$ & & & & \\
\hline & $\begin{array}{l}\text { I was given ample opportunity to practise the skills I was } \\
\text { asked to learn. }\end{array}$ & & & & \\
\hline \multirow{2}{*}{ Evaluation } & I was given ample opportunity to demonstrate my knowledge. & & & & \\
\hline & I was given ample opportunity to demonstrate my skills. & & & & \\
\hline \multirow{2}{*}{ Facility } & $\begin{array}{l}\text { I found the environment to complete my questions to be } \\
\text { comfortable. }\end{array}$ & & & & \\
\hline & $\begin{array}{l}\text { I experienced minimal distractions while answering the } \\
\text { questions. }\end{array}$ & & & & \\
\hline
\end{tabular}

\section{Standardised test}

The standardised test which was also administered through the online micro-learning system, required students to either opened a web browser on their computers or access the application from their mobile devices. The micro-learning system scored the test and immediately returned a score to the participant. Of the four standardised tests considered for this research, 6207 members of staff completed Test 1, 3608 staff participated in Test 2, 5299 staff members took Test 3, and 5715 members participated in Test 4 . A total of 277 multiple choice questions were included across the four standardised test.

\section{Correlation test}

In order to evaluate Level 3 and Level 4 of the Kirkpatrick Model, as required, a correlational test was used to determine the relationship between micro-learning and behaviour change (Level 3), and business metrics (Level 4). More specifically, the correlation tests were used to firstly examine the relationship between the time spent on micro-learning in one year, and the 
change in the performance ratings over the same period, among 1665 members of staff, and secondly the relationship between the time spent on micro-learning during one year and a change in sales over the same period of 3455 staff members. The time data was extracted from the micro-learning platform, the performance rating data was extracted from the performance management platform, and the sales data was extracted from the sales management platform.

\section{RESEARCH FINDINGS}

Based on the results in Table 2, it can be concluded that most learners did react positively to the micro-learning programmes, and just over a third of the respondents were of the opinion that their micro-learning experience could have been improved with the assistance of a facilitator, and almost a quarter of the respondents felt they experienced too many distractions while answering the questions.

Table 2: Summary of responses to satisfaction

\begin{tabular}{|c|c|c|c|c|c|c|c|}
\hline & Statement & $\begin{array}{c}\text { No } \\
\text { Response }\end{array}$ & $\begin{array}{l}\text { Strongly } \\
\text { Disagree }\end{array}$ & Disagree & Agree & $\begin{array}{l}\text { Strongly } \\
\text { Agree }\end{array}$ & Total (n) \\
\hline 1) & $\begin{array}{l}\text { I understood the learning } \\
\text { objectives. }\end{array}$ & 110 & $2 \%$ & $2 \%$ & $51 \%$ & $45 \%$ & 5850 \\
\hline 2) & $\begin{array}{l}\text { I was able to relate to each of the } \\
\text { learning objectives. }\end{array}$ & 36 & $2 \%$ & $3 \%$ & $52 \%$ & $43 \%$ & 5924 \\
\hline 3) & $\begin{array}{l}\text { I was appropriately challenged by } \\
\text { the material. }\end{array}$ & 29 & $6 \%$ & $14 \%$ & $48 \%$ & $32 \%$ & 5931 \\
\hline 4) & $\begin{array}{l}\text { The course material was easy to } \\
\text { navigate. }\end{array}$ & 12 & $2 \%$ & $4 \%$ & $51 \%$ & $43 \%$ & 5948 \\
\hline 5) & $\begin{array}{l}\text { I felt that the course material will } \\
\text { be essential for my success. }\end{array}$ & 26 & $2 \%$ & $4 \%$ & $50 \%$ & $44 \%$ & 5934 \\
\hline 6) & $\begin{array}{l}\text { The material was relevant to my } \\
\text { needs. }\end{array}$ & 50 & $2 \%$ & $3 \%$ & $50 \%$ & $44 \%$ & 5910 \\
\hline 7) & $\begin{array}{l}\text { My learning could have been } \\
\text { advanced if I had a facilitator share } \\
\text { their knowledge with me. }\end{array}$ & 25 & $9 \%$ & $29 \%$ & $40 \%$ & $22 \%$ & 5935 \\
\hline 8) & $\begin{array}{l}\text { My learning was enhanced by the } \\
\text { Discovery Zone. }\end{array}$ & 67 & $3 \%$ & $7 \%$ & $54 \%$ & $36 \%$ & 5893 \\
\hline 9) & $\begin{array}{l}\text { My learning could have been } \\
\text { advanced if I had a facilitator share } \\
\text { their experiences with me. }\end{array}$ & 20 & $10 \%$ & $29 \%$ & $39 \%$ & $22 \%$ & 5940 \\
\hline 10) & $\begin{array}{l}\text { I was engaged during the course of } \\
\text { the programme. }\end{array}$ & 26 & $3 \%$ & $7 \%$ & $53 \%$ & $37 \%$ & 5934 \\
\hline 11) & $\begin{array}{l}\text { I was able to get actively involved } \\
\text { during the course of the } \\
\text { programme. }\end{array}$ & 39 & $3 \%$ & $5 \%$ & $52 \%$ & $40 \%$ & 5921 \\
\hline 12) & $\begin{array}{l}\text { I was comfortable with the pace of } \\
\text { the programme. }\end{array}$ & 36 & $2 \%$ & $4 \%$ & $52 \%$ & $42 \%$ & 5924 \\
\hline 13) & $\begin{array}{l}\text { I was comfortable with the duration } \\
\text { of the programme. }\end{array}$ & 23 & $3 \%$ & $4 \%$ & $52 \%$ & $41 \%$ & 5937 \\
\hline 14) & $\begin{array}{l}\text { I was given ample opportunity to } \\
\text { get answers to my questions. }\end{array}$ & 0 & $2 \%$ & $4 \%$ & $52 \%$ & $41 \%$ & 5960 \\
\hline 15) & $\begin{array}{l}\text { I was given ample opportunity to } \\
\text { practise the skills I was asked to } \\
\text { learn. }\end{array}$ & 46 & $3 \%$ & $6 \%$ & $52 \%$ & $40 \%$ & 5914 \\
\hline 16) & $\begin{array}{l}\text { I was given ample opportunity to } \\
\text { demonstrate my knowledge. }\end{array}$ & 25 & $2 \%$ & $6 \%$ & $52 \%$ & $40 \%$ & 5935 \\
\hline 17) & $\begin{array}{l}\text { I was given ample opportunity to } \\
\text { demonstrate my skills. }\end{array}$ & 59 & $3 \%$ & $7 \%$ & $52 \%$ & $38 \%$ & 5901 \\
\hline
\end{tabular}




\begin{tabular}{|c|c|c|c|c|c|c|}
\hline Statement & $\begin{array}{c}\text { No } \\
\text { Response }\end{array}$ & $\begin{array}{c}\text { Strongly } \\
\text { Disagree }\end{array}$ & Disagree & Agree & $\begin{array}{c}\text { Strongly } \\
\text { Agree }\end{array}$ & Total (n) \\
\hline $\begin{array}{c}\text { 18) I found the environment to } \\
\text { complete my questions to be } \\
\text { comfortable. }\end{array}$ & 41 & $3 \%$ & $6 \%$ & $50 \%$ & $41 \%$ & 5919 \\
\hline $\begin{array}{c}\text { 19) I experienced minimal distractions } \\
\text { while answering the questions. }\end{array}$ & 77 & $7 \%$ & $17 \%$ & $45 \%$ & $30 \%$ & 5883 \\
\hline
\end{tabular}

In the standardised tests, learners had to achieve above 80 per cent to be considered as having successfully passed. Figure 1 reflects the percentage of learners that passed and failed each of the quarterly standardised tests. From the data depicted in Figure 1, it can be summarized that overall, for each of the quarters, the number of people who passed outweighs the number of people who didn't pass. It can therefore be concluded that learners will acquire knowledge when participating in a micro-learning programme. More specifically at least four out of every five learners acquired enough knowledge needed to meet the pass mark of the standardised test.

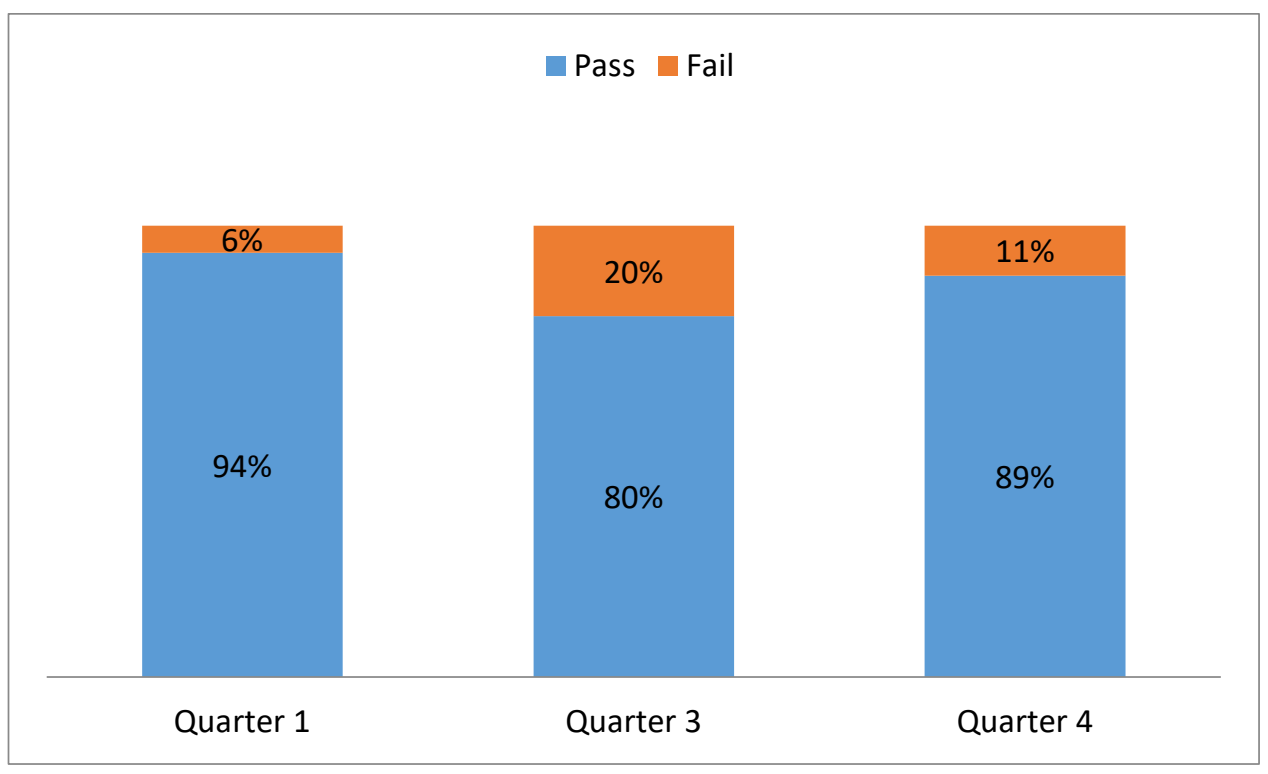

Figure 1: Pass and fail percentage per quarter

A correlation test (Table 3), was used to examine the relationship between the time spent on the micro-learning platform engaging with content, and taking the standardised tests during the one-year period from October 2017 to September 2018, and a change in performance ratings over the same one-year period, to establish the effectiveness of micro-learning at Level 3 of the Kirkpatrick Model.

Table 3: Time spent on micro-learning platform and change in performance ratings

\begin{tabular}{|c|c|c|}
\hline Correlation & 6-month rating score & 12-month rating score \\
\hline Time spent on micro-learning platform & 0.011137629 & 0.023351753 \\
\hline
\end{tabular}

As indicated in Table 3, the correlation between the time spent on micro-learning and the 
change in performance over six months and over one year respectively. This correlation score implies that a person spending one hour on micro-learning versus someone spending 50 hours on micro-learning was not expected to perform better or worse in their performance ratings because of their time spent with content on the micro-learning platform. Upon closer inspection of the data, it was identified that the overall summary is skewed by outliers. As depicted in Figure 2, the graph represents five different ranges of time spent in hours on the micro-learning platform, and the trend line indicates the change in performance ratings correlated to each range of time.

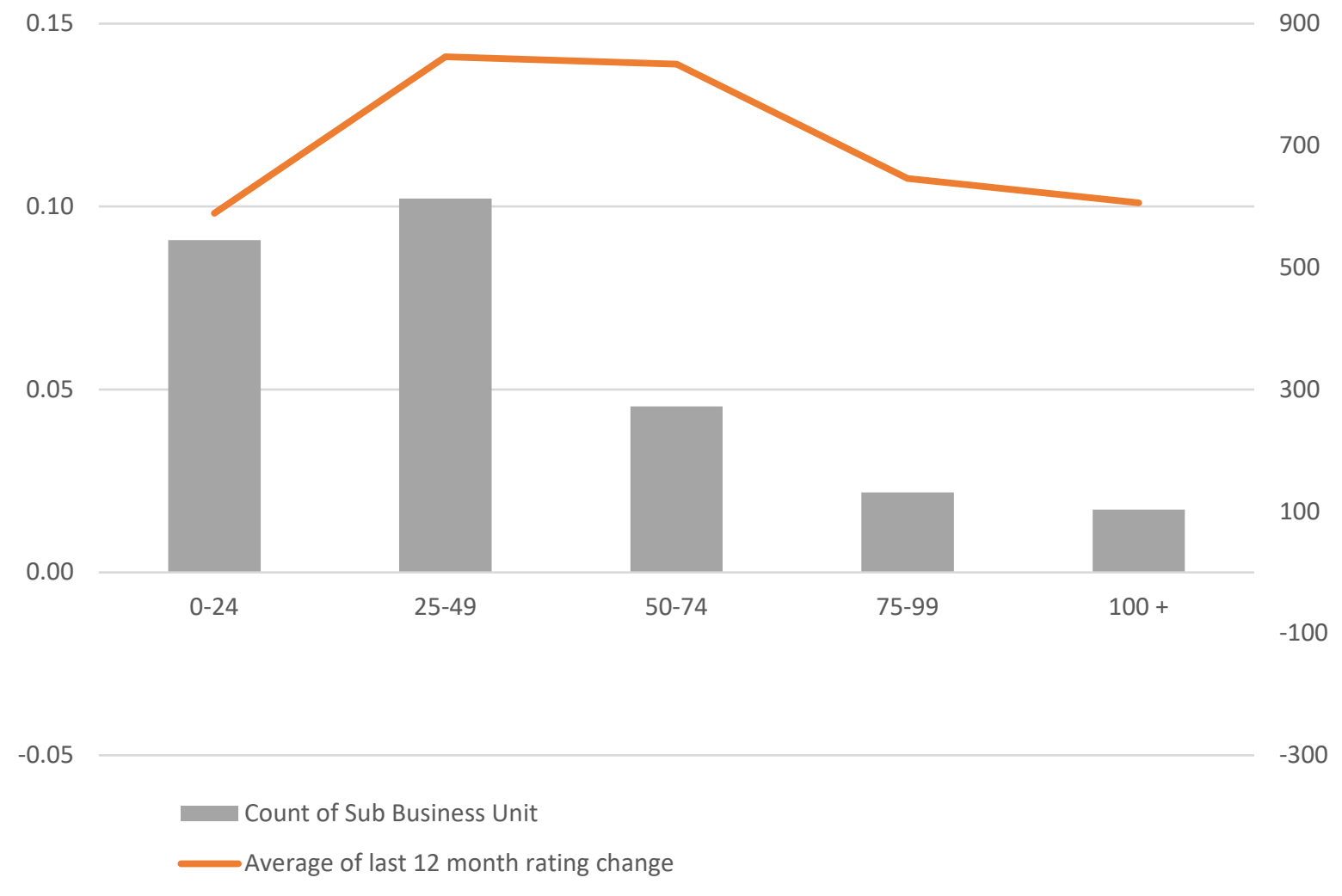

Figure 2: Improvement in performance per time spent range

Using the trend line depicted in Figure 2, it can be concluded that:

- There is an upward trend initially, followed by a downward trend, which trends cancel each other, which is why the correlation test results shows a 0.0 correlation.

- The upward trend between the time spent on micro-learning and the improvement in performance ratings correlates until 65 hours, for 1430 of the 1664 participants, thus implying that for 86 per cent of the staff, there was a correlation between their improvement in performance and the time they spent on micro-learning.

The aim of level 4 evaluation was to determine if there was an improvement in business metrics 
of staff who participated in a micro-learning programme. With regard to Level 4 of the Kirkpatrick Model, Table 4 provides the average number of products sold in 2017 compared to the average number of products sold in 2018 , correlated between two groups, namely, those who spent less than 20 hours on the micro-learning platform and those who spent more than 20 hours on the micro-learning platform. The reason for the 20 -hour cut off mark is that 20 hours represents the total time over a one-year period if a learner dedicated 1 per cent of their working hours to learning and development.

From the data in Table 4 and depiction in Figure 3, it can be deduced that:

- Sales in the insurance product category saw the highest improvement.

- Sales in the savings product category saw a decline in sales for both categories of learners.

- For each of the five product categories, the rate of improved sales is better for staff who spent more than 20 hours on the micro-learning platform and, overall, staff who spent more than 20 hours on learning sold on average six percent more products in 2018 compared to staff who spent less than 20 hours on the micro-learning platform and only increased their sales on average by one percent.

From the above, it can be concluded that there will indeed be a positive improvement in business metrics where learners have participated in a micro-learning programme. More specifically, the results indicated that staff who spend at least five minutes a day on microlearning will improve sales at least five times as much as staff who do not spend five minutes a day on micro-learning.

\section{DISCUSSION AND RECOMMENDATIONS}

\section{Value and Improvement of the micro-learning programme}

It was ascertained that the respondents were very satisfied with the micro-learning programme, which confirms that most learners are interested in learning via electronic devices and will welcome a new and smart version of software that can deliver micro-content to transform knowledge (Jomah et al. 2014). Kirkpatrick and Kirkpatrick (2005) also postulate that the other value of the Level 1 evaluation is the opportunity to obtain suggestions for future improvements of the learning intervention. Thus, based on the data, two key improvements were identified, the first being that the micro-learning programme should incorporate an opportunity for learners to interact with facilitators who can share their knowledge and experience. This finding 
Table 4: Comparison of product sales per category between 2017 and 2018 as at November 2018

\begin{tabular}{|c|c|c|c|c|c|c|c|c|c|c|c|c|}
\hline Product Category & \multicolumn{2}{|c|}{ Loans } & \multicolumn{2}{|c|}{ Savings } & \multicolumn{2}{|c|}{ Credit Card } & \multicolumn{2}{|c|}{ Insurance } & \multicolumn{2}{|c|}{ Facility } & \multicolumn{2}{|c|}{ Total Products } \\
\hline $\begin{array}{l}\text { Time range spent on micro-learning } \\
\text { during the year }\end{array}$ & $\begin{array}{l}<20 \\
\text { hours }\end{array}$ & $\begin{array}{c}>20 \\
\text { hours }\end{array}$ & $\begin{array}{c}<20 \\
\text { hours }\end{array}$ & $\begin{array}{c}>20 \\
\text { hours }\end{array}$ & $\begin{array}{l}<20 \\
\text { hours }\end{array}$ & $\begin{array}{l}>20 \\
\text { hours }\end{array}$ & $\begin{array}{l}<20 \\
\text { hours }\end{array}$ & $\begin{array}{c}>20 \\
\text { hours }\end{array}$ & $\begin{array}{c}<20 \\
\text { hours }\end{array}$ & $\begin{array}{c}>20 \\
\text { hours }\end{array}$ & $\begin{array}{l}<20 \\
\text { hours }\end{array}$ & $\begin{array}{c}>20 \\
\text { hours }\end{array}$ \\
\hline $\begin{array}{l}\text { Average no. of products sold per } \\
\text { consultant per month in } 2017 \text { (a) }\end{array}$ & 6.76 & 7.39 & 34.42 & 36.24 & 2.28 & 1.87 & 11.42 & 13.53 & 1.64 & 1.52 & 56.53 & 60.56 \\
\hline $\begin{array}{l}\text { Average no. of products sold per } \\
\text { consultant per month in } 2018 \text { (b) }\end{array}$ & 6.75 & 7.58 & 31.89 & 34.74 & 2.71 & 2.40 & 13.68 & 17.69 & 1.97 & 1.94 & 57.00 & 64.36 \\
\hline $\begin{array}{l}\text { Difference between } 2017 \text { and } 2018 \\
\text { values }(a)-(b)=(c)\end{array}$ & -0.01 & 0.19 & -2.53 & -1.50 & 0.43 & 0.53 & 2.26 & 4.16 & 0.33 & 0.42 & 0.47 & 3.80 \\
\hline Percentage rate of change $(c) /(a)^{*} 100$ & $0 \%$ & $3 \%$ & $-7 \%$ & $-4 \%$ & $19 \%$ & $29 \%$ & $20 \%$ & $31 \%$ & $20 \%$ & $27 \%$ & $1 \%$ & $6 \%$ \\
\hline
\end{tabular}

\section{$<20 \mathrm{hrs}$ vs. $>20 \mathrm{hrs}$ rate of change per product}

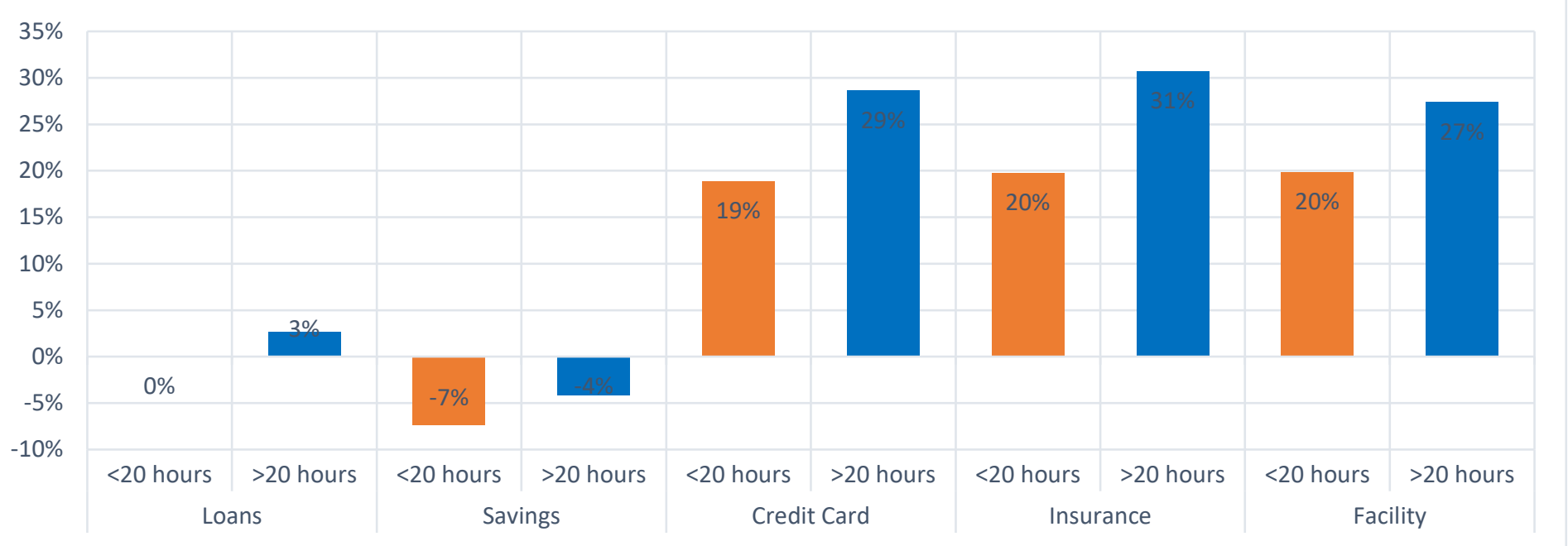

Figure 3: Improvement in product sales per category based on time spent on micro-learning 
is supported by research from educational theorists, like Ettienne Wegner, around the social element in learning. As Wegner puts it, humans are social by nature, this fact cannot be trivialised as it is a central aspect of learning. People want to be able to talk about shared historical frameworks and engage in learning as a social participant (Illeris 2009).

The second recommendation for improvement is around the reduction of distractions during interactions with the micro-learning platform. One of the assumptions of learning through reading is that reading means sustained, uninterrupted, analytical, or contemplative work - in other words, focused attention (Davidson 2011). However, the modern learner has grown adept at multitasking and being constantly distracted as frequently as once every five minutes (Deloitte 2014). Distraction has become our natural state according to Davidson (2011), and to counteract this, she recommends that humans will have to develop new selfcontrol and self-regulation habits to conquer constant distractions. This will become crucial, given that a key characteristic of micro-learning is the "anytime and anywhere" enabled technology and that it is unlikely the digital overload will be reduced in this information era.

\section{Barriers to learning in micro-learning}

In any training programme, there are three main objectives, namely, to gain knowledge, learn new skills and/or increase present skills, or change mindsets (Kirkpatrick and Kirkpatrick 2007). In this research, Level 2 was aimed at determining whether the acquisition of knowledge had taken place. While the findings showed that most learners did acquire the knowledge required to pass with 80 per cent, in Test 2 , one in every five learners did not pass. The three factors that could influence this learning transfer are the design of the training programme, inherent characteristics of the trainee, and the holistic work environment (Ford and Weissbeinn 1997). Since the assessment of these characteristics was not included in the scope of this research, it is recommended that these factors are further investigated. What should be noted according to Galloway (2005), is that barriers to learning transfer will continue to exist. Therefore, despite the benefits of a micro-learning programme, micro-learning is not the panacea of learning, and barriers to learning will continue to impact the success of any learning programme.

\section{Micro-learning and performance}

The literature review indicated that even with well-informed and clearly defined quantitative learning objectives, these objectives cannot guarantedd how the trainees will transfer learning to job performance. Numerous empirical studies and meta-analysis revealed disconnect 
between learning and behaviour (Grossman and Salas 2011), and this was confirmed in the correlation test results obtained in this study. However, it can be argued the data was skewed by outliers, as a closer analysis showed that for some participants, there was a positive correlation between the time spent on micro-learning and improvement in their performance. However, the literature review did point to three of a learner's inherent characteristics, namelycognitive ability, self-efficacy and level of motivation (Grossman and Salas 2011), since these factors may impact the transfer of learning. Kirkpatrick and Kirkpatrick (2007) added that the lack of opportunity to apply what has been learnt and/or applying what has been learnt in an environment that doesn't support the new knowledge, can make it more complicated and difficult to establish learning transfer in workplace performance.

\section{The relationship between the time committed to learning and the bottom line}

The fourth level of the assessment attempted to measure if training that directly affected the organisation's bottom line. The correlation test results revealed that learners who spent at least five minutes a day on micro-learning would improve their sales by six times, compared to respondents who did not commit to five minutes a day. Thus, even though learners only have a meagre one percent of their working day (which equates to 4,8 minutes in an eight-hour working day), to commit to learning, as indicated in the literature review, if they dedicate this time to learning what is required for them to remain relevant, it will enable them to improve their sales (performance).

\section{CONCLUDING REMARKS}

With global connectivity and technology, future models of education face the difficult task of embracing the fluid nature of rapidly changing knowledge, while simultaneously attending to the political and organisational structures created to capture and solidify knowledge (Hug 2006). Although micro-learning is promising in that it presents an interesting concept on which to build future models of education (Siemens 2007), the challenge for micro-learning is that because it is still a relatively new concept that has hardly been empirically examined to date, (Bruck 2006) there is not a robust model to work with as a starting point, (Hagleitner and Hug 2007). Instead, it is fragments from different discourses and practices that are available to researchers as a point of departure (Hug 2006), and given the developing and fragmented nature of the technologies and architectures associated with micro-learning, it is unlikely that a definitive consensus of micro-learning theory and technology will emerge (Hug and Friesen 2007). 
The Kirkpatrick Model does however provide a technique for evaluating learning outcomes and determining the extent to which the objectives at four different levels have been achieved. Thus, with the appropriate blend of data, a learning department can create a chain of evidence leading from learning interventions to results (Kirkpatrick and Kirkpatrick 2007). The findings of this study aimed at creating this chain of evidence for a micro-learning programme, with each level providing evidence which contributed to the overall picture of how training contributes to bottom-line results. Thus, none of the levels are viewed in isolation of the other during the final analysis of the data and the overall findings of the study have implications for the successful integration of micro-learning into an organisation's learning strategy.

\section{RESEARCH CONTRIBUTIONS}

With the advent of the internet and subsequent rapid changes in technology, learning has changed in terms of how people learn, with whom they learn, and by what means they learn. This has had profound implications for adult learners in the workplace, where workplace learning provides a competitive advantage in an organisation's human capital as well as contributes towards the fiscal bottom line. Microlearning, as a concept defined by the ability to access small units of narrow topics that form part of an inter-connected curriculum, via an "anytime and anywhere"-enabled technology platform, in under 15 minutes, has the benefit of allowing the adult learner to take their learning beyond the boundaries of a bricks-and-mortar learning environment, and enables them to integrate their learning into their daily lives by reducing the overflow and complexity of information. Furthermore, microlearning supports a fundamental tenet of adult learning, in that it enables self-directed learning because it allows learners to choose the time, place and pace of their learning.

\section{LIMITATIONS AND SCOPE}

It is acknowledged that a limitation of quantitative analysis is that correlation does not imply causation and that numerical data doesn't enable the researcher to probe the results and explore potential causes as would be the case with qualitative research (Apuke 2017).

It is expected that the results of this study will be generalisable to other retail banking organisations and learning environments where staff are already familiar with the knowledge required to fulfil their roles. It may have limited applicability in specialised knowledge worker contexts such as medicine, where knowledge and skills required to be competent in a role are assumed to be more sophisticated, and environments were staff are complete novices and do not have any experience in their roles. 


\section{REFERENCES}

Abel, M.-H., C. Moulin and D. Lenne. 2006. Learning organizational memory and microlearning (Semantics for Microlearning). 275 file:///C:/Users/f4892844/OneDrive\%20-\%20FRG/ Downloads/Learning_Organizational_Memory_and_Microlearning_S.pdf (Accessed 21 April 2020)

Abernathy, D. J. 1992. Thinking outside the evaluation box. Training and Development 53. https://www.researchgate.net/publication/234607066_Thinking_Outside_the_Evaluation_Box

Alliger, G. M. and E. A. Janak. 1989. Kirkpatrick's levels of training criteria: Thirty years later. Personnel Psychology. https://onlinelibrary.wiley.com/doi/epdf/10.1111/j.1744-6570.1989. tb00661.x?r3 referer=wol

Apuke, O. 2017. Quantitative research methods: A synopsis approach. Arabian Journal of Business and Management: 40-47. file:///C:/Users/laptop/Downloads/QUANTITATIVERESEARCHA SYNOPSISAPPROACH\%20(1).pdf

Asano, E. 2017. How much time do people spend on social media? https://www.socialmedia today.com/marketing/how-much-time-do-people-spend-social-media-infographic (Accessed 17 December 2018)

Axonify. 2019. The microlearning platform that's made for frontline workers. https://axonify.com/ microlearning-platform/ (Accessed 14 January 2019).

Bates, R. 2004. A critical analysis of evaluation practice: The Kirkpatrick model and the principle of beneficence. Evaluation and programme planning 27: 341-347.

Bell, B. S., S. I. Tannenbaum, K. J. Ford, R. A. Noe and K. Kraiger. 2017. 100 Years of training and development research: What we know and where we should go. Journal of Applied Psychology: 305-323. https://www.researchgate.net/profile/Raymond_Noe/publication/312957891_100 Years_of_Training and Development_Research_What_We_Know_and_Where_We_Should_G o/links/5936bf56aca272327c3070f7/100-Years-of-Training-and-Development-Research-WhatWe-Know-and-Where-

Bersin, J. 2018. A new paradigm for corporate training: Learning in the flow of work. https://joshbersin.com/2018/06/a-new-paradigm-for-corporate-training-learning-in-the-flow-ofwork/ (Accessed 8 January 2019).

Bloem, J., M. van Doorn, S. Duivestein, D. Excoffier, R. Maas and E. van Ommeren. 2014. The fourth industrial revolution. Things to tighten the link between It and OT. https://www.fr.sogeti. com/globalassets/global/downloads/reports/vint-research-3-the-fourth-industrial-revolution (Accessed 18 December 2018).

Brand South Africa. 2012. FNB named world's most innovative bank. https://www.brand southafrica. com/investments-immigration/business/success/fnb-011112 (Accessed 5 January 2019).

Brooks, A. 1990. Making trouble in corporate America: Critical reflection within a Fortune 100 Company. Adult Education Research Conference, 31-36. Georgia: The University of Georgia.

Bruck, P. A. 2006. Mircolearning as strategic research field: An invitation to collaborate. In Microlearning: Emerging Concepts, Practices and Technologies after e-Learning, 13-16. Innsbruk: Innsbruk University Press.

Buchem, I. and H. Hamelmann. 2010. Microlearning: A strategy for ongoing professional development. eLearning Papers, 1-15.

BusinessTech. 2018. 6 New banks launching in South Africa soon. https://businesstech.co.za/ news/banking/260077/6-new-banks-launching-in-south-africa-soon/ (Accessed 19 December 2018).

Camarate, J. and S. Brinckmann. 2017. The future of banking: A South African perspective. 
Johannesburg: PWC. https://www.pwc.co.za/en/assets/pdf/strategyand-future-of-banking.pdf (Accessed 6 March 2019).

Compare Banks. 2014. South African deposits. https://south-africa.deposits.org/banks.html (Accessed 4 January 2019).

Creswell, J. W. 2014. Research design. Los Angeles: SAGE.

Davidson, C. N. 2011. Now you see it: How the brain science of attention will transform the way we live, work, and learn. New York: Viking.

Deloitte. 2014. Leading in learning. https://www2.deloitte.com/content/dam/Deloitte/global/ Documents/HumanCapital/gx-cons-hc-learning-solutions-placemat.pdf (Accessed 20 December 2018).

Deloitte. 2017. 2017 Deloitte global human capital trends: Rewriting the rules for the digital age. Deloitte University Press. https:/www2.deloitte.com/content/dam/Deloitte/global/Documents/ About-Deloitte/central-europe/ce-global-human-capital-trends.pdf (Accessed 18 December 2018).

Downes, A. 2019. Essentials of learning evaluation: A foundation for effectively measuring learning's impact. $\quad$ https://www.watershedlrs.com/hubfs/DOCUMENTS/Essentials_of_Learning Evaluation.pdf (Accessed 10 February 2019).

Eades, J. 2015. Why learning and development is the most important department. https://elearning industry.com/why-learning-and-development-is-the-most-important-department (Accessed 19 December 2018).

Ford, K. J. and D. A. Weissbeinn. 1997. Transfer of training: Updated review and analysis. Performance Improvement Quarterly 10. file://C:/Users/f4892844/Downloads/Transfer_of_Training_An_ Updated_Review_and_Analysi.pdf

FutureThink. 2009. The future of learning \& development. New York: Future Think LLC.

Galloway, D. L. 2005. Evaluationg distance delivery and e-learning: Is Kirkpatrick's model relevant? Performance Improvement 44(4). https://onlinelibrary.wiley.com/doi/epdf/10.1002/pfi. 4140440407?r3_referer $=$ wol

Grossman, R. and E. Salas. 2011. The transfer of training: What really matters. International Journal of Training and Development. https://pdfs.semanticscholar.org/ab9d/0067292ef59e084476a244 b9210d1faaab8d.pdf

Hagleitner, W. and T. Hug. 2007. A generative model for evaluation of the microlearning processes. In Didactics of microlearning, 381. Munster: Waxmann.

Harasim, L. M. 2012. Learning theory and online technologies. New York: Routledge.

Haythornthwaite, C. and R. Andrews. 2011. E-Learning theory and practice. London: Sage.

Henning, E., W. van Rensburg and B. Smit. 2004. Finding your way in qualitative research. Pretoria: Van Schaik.

Hierdeis, H. 2007. From meno to microlearning: A historical survey. In Didactics of Microlearning, 35. Munster: Waxmann.

Hug, T. 2006. Microlearning: A new pedagogical challenge. In Microlearning: Emerging concepts, practices and technologies after e-Learning, 7-12. Innsbruck: Innsbruck University Press.

Hug, T. 2007. Didactics of microlearning - Introductory note. In Didactics of Microlearning, 10-14. Munster: Waxmann.

Hug, T. and N. Friesen. 2007. Outline of a microlearning agenda. In Didactics of Microlearning, 1534. Munster: Waxmann.

Illeris, K. 2009. Contemporary theories of learning: Learning theorists ... In their own words. London: Routledge. https://books.google.co.za/books?hl=en\&lr=\&id=vQWPAgAAQBAJ\&oi=fnd\&pg $=\mathrm{PA} 209 \& \mathrm{dq}=$ learning + must + be + social\&ots=Nx17DDJLNh\&sig=USkMo6T5KUaP9P8qhC2G 
6m6RMjE\#v=onepage \&q=learning $\% 20$ must $\% 20 \mathrm{be} \% 20$ social $\& \mathrm{f}=$ false

Isaias, P., J. M. Spector, D. Ifenthaler and D. G. Sampson. 2015. E-Learning systems, Environments and approaches. Switzerland: Springer.

Job, M. A. and H. G. Ogalo. 2012. Microlearning as innovative process of knowledge strategy. International Journal of Scientific and Technology Research 1(11): 92. www.elearningpapers.eu: http://citeseerx.ist.psu.edu/viewdoc/download?doi=10.1.1.300.3139\& $\quad$ rep=rep1\&type=pdf (Accessed 19 December 2018).

Jomah, O., A. K Masoud, P. X. Kishore and S. Aurelia. 2014. Microlearning: A modernized education system. BRAIN (Broad Research in Artifical Intelligence and Neuroscience): 103-110. http://www.edusoft.ro/brain/index.php/brain/article/view/582/627

Jugmohan, L. 2016). FNB is Africa's most innovative bank 2016. http://www.digitalstreetsa.com/fnbafricas-innovative-bank-2016/ (Accessed 17 December 2018).

Kapur, S. 2015. Andragogy: The adult learning theory. Indian Journal of Adult Education, 50-60.

Kaufman, R., J. Keller and R. Watkins. 1996. What works and what doesn't: Evaluation beyond Kirkpatrick. Performance Improvement: 1-37.

Kirkpatrick, D. L. and J. D. Kirkpatrick. 2005. Transferring learning to behaviour - Using the four levels to improve performance. San-Francisco: Berrett-Koehler Publishing Inc.

Kirkpatrick, D. L. and J. D. Kirkpatrick. 2007. Implementing the four levels. San-Francisco: BerrettKoehler Publishers Inc.

Knowles, M. S., E. F. Holton and R. A. Swanson. 2012. The adult learner: The definitive classic in adult education and human resource development. $7^{\text {th }}$ Edition. New York: Routledge.

Le Clus, M. A. 2011. Informal learning in the workplace: A review of the literature. Australian Journal of Adult Learning 355-373.

Nanziri, E. L. and M. Leibbrandt. 2018. Measuring and profiling financial in South Africa. South African Journal of Economic and Management Sciences: 1-17. http://www.scielo.org.za/ pdf/sajems/v21n1/47.pdf

Neuhold, E. and M. Lindner. 2007. Quo Vadis, eLearning? Microlearning: Emerging concepts, practices and technologies after e-learning, 20. Innsbruck: Innsbruck University Press.

PWC. 2014. Retail banking 2020: Evolution or revolution. https://www.pwc.com/gx/en/bankingcapital-markets/banking-2020/assets/pwc-retail-banking-2020-evolution-or-revolution.pdf (Accessed 19 December 2018).

PWC. 2015. The future shape of financial services in Africa. https://www.pwc.co.za/en/assets/pdf/fsjournal-2015.pdf (Accessed 20 December 2018).

Rainbird, H., A. Fuller and A. Munro. 2004. Workplace learning in context. London: Routledge.

Saniee, I., S. Kamat, S. Prakash and M. Weldon. 2017. Will productivity growth return in the new digital era? Bell Labs Technical Journal 22: 4. https://ieeexplore.ieee.org/stamp/ stamp.jsp?tp=\&arnumber $=7951155 \&$ isnumber $=7951154$

SARB. 2017. Bank Supervision Department Annual Report 2017. https://www.resbank.co.za/ Lists/News\%20and\%20Publications/Attachments/8507/01\%20BankSupAR2017.pdf (Accessed 4 January 2019).

Schmidt, C. 2007. Small steps towards a culture of deliberative learning: Media supported pyramid discussions. In Didactics of microlearning, 313. Munster: Waxmann.

Siemens, G. 2007. Connectivism: Creating a learning ecology in distributed environments. In Didactics of Microlearning, 53. Munster: Waxmann.

Spira, J. 2010. The knowledge worker's day: Our findings. http://www.basexblog.com/2010/11/04/ourfindings/ (Accessed 16 December 2018). 
Spitzer, D. R. 2005. Learning effectiveness measurement: A new approach for measuring and managing learning to achieve business results. Advances in Developing Human Resources 7.

Statista. 2018. Number of smartphone users in South Africa. https://www.statista.com/statistics/ 488376/forecast-of-smartphone-users-in-south-africa/ (Accessed 17 December 2018).

Strother, J. B. 20021. An assessment of the effectiveness of e-learning in corporate training programmes. International Review of Research in Open and Distance Learning 3(1). file://C:/Users/f4892844/Downloads/83-315-2-PB.pdf

The Banking Association of South Africa. 2014. South African Banking Sector Overview. https://www.banking.org.za/docs/default-source/publication/banking-sector-overview.pdf? sfvrsn $=6$ (Accessed 4 January 2019).

Younus, U. M. 2017. Fourth industrial revolution. https://www.dawn.com/news/1331909 (Accessed 18 December 2018). 